\section{The Crest of the Wave: ADVENTURES in Oceanography}

\author{
By Willard Bascom \\ 1988. $318 \mathrm{pp}$. \$19.95, hardbound \\ Harper and Row, New York
}

\section{If your buckles need swashing. look no further.}

THE second World War ushered in a new era of oceanography, championed by entrepreneurs. driven by national needs. and fueled by federal dollars. The new protagonist was invariably male, ruggedly handsome, and chafing to go forth and tame the sea. Explorers and adventurers were our unsurpassed heros, and oceanographers worth their salt had the right stuft, although at the time nobody knew what to call it.

Willard Bascom is a post-war oceanographer. His new book chronicles adventures that begin underground in Colorado mines, where he drills and blasts through the hard rock of youth, shrugging off dangers and wishing for more. One night, fate intervenes. in the person of John Isaacs, who offers cosmoline cocktails in lieu of black powder boilermakers. Bascom succumbs to siren songs of the sea, and soon he is surveying Pacific beaches, crashing and bashing through twenty-foot combers in a surplus amphibious Army "dukw." Manly endeavors, these; the timid and the cautious need not apply.

Bascom rapidly pushes seaward, forecasting seismic waves, salvaging stranded ships, and helping the Navy with amphibious landings. Tales of exotic islands and languid archipelagoes emerge against a backdrop of Scripps Institution's Capricorn Pacific expedition, during which Bascom serves as chief entrepreneur and head grenadier, with Isaacs hovering nearby as revered scientific guru. The book paints a threadbare but probably accurate picture of ironman oceanography, with rough-and-

David A. Brooks, Department of Oceanography, Texas A\&M Liniversiti. College Station. 7784.3

Editor's Note: In addision to re'tews of scientitic hooks. we will occasiomally puhlssh thumbnail sketches of works that may have wider appeal. This caterny could include, for example. hrief reviens of novels. biographies, and historical ane dotes - the only requirements are relevance to the ocean and interest to the reader. We solicit well-prepared revien's in either the scientific or the thumbnail vein: the latter will carry the banner "Short Takes." tough camaraderie the order of the day and women mostly relegated to pastimes of the port. If you identify with Chuck Yeager and envy Red Adair, if John Wayne is your role model, you'll feel right at home with Bascom 's to-hell-with-the-sharks approach to oceanography. He is Rambo of the deep, the high priest of nautical big-think.

The author"s work with seismic waves led him to a first-hand involvement in the Pacific nuclear tests of the 1950s, and through his eyes the explosions that decimated Bikini and other atolls are freshly awesome and horrific. We hear of the naiveté of the personnel who watched the tests, and we are reminded of innocent fishermen who died from radiation poisoning. From close range, Bascom vividly describes searing fireballs unleashed on a world unprepared to deal with them. Tough-guy scenes before an atomic blast starkly contrast with a poignant image of "a pair of fairy terns, blinded by the explosion, stumbling about in a clearing." Reminded of the madness, readers can only hope to escape the terns' fate.

The final third of the book continues with greater velocity but lesser impact. After the bomb tests, Bascom successively applies his special talents to deep-ocean drilling, diamond mining off Africa, treasure-hunting in the Bahamas, and windpowered research vessels. Each of these is a tale in itself, each farther from mainline oceanography, and each an example of the author's swashbuckling style. In a few cases-for example, during the search for Spanish gold-plans go awry, and the acid residue can be tasted in the text. On the other hand, the early drilling program and its quest for the "Moho"lead directly to the presently successful ocean drilling program. And one cannot fail to be impressed by the author's creative response to the last energy crisis: a grand research schooner, fourmasted. computer controlled, and named, with characteristic modesty, the R/V Willard Bascom.

Bascom's latest book reflects a time when raw energy, inventive talent, and personal charisma carried the day. The book is a sequence of adventures drawn from the author's experiences, written in the style of an embellished diary: it is not a sea story or a novel, with developed characters and connective tissue. The Crest of the Wave offers an insightful and entertaining view of oceanography when it was rapidly developing in the United States. Some readers may be put off by the author's abundant hubris, but many will appreciate his unbounded enthusiasm for new ideas.

\section{ENRICHING THE GRADUATE EXPERIENCE}

\author{
By Michael McClain \& Charles Harden
}

$\mathrm{G}$ JRADUATE school is a training ground for prospective scientists, a gateway between the classroom and the scientific community. It is during this tutelage that students develop their most prominent skills: the ability to ask the right question: answer that question through scientific investigation, and communicate their results to colleagues and the public. The mastery of these skills is essential in the development of a creditable scientist, and the extent to which these skills may be developed in an institution is a measure of the quality of that institution. Training in these skills, however, need not be the responsibility of the institution alone. but may come from the students themselves. Such is the case at the Rosenstiel School of Marine and Atmospheric Science (RSMAS) where, as in other institutions. students are augmenting their own education.

The Rosenstiel School is a relatively autonomous branch of the University of Miami. consisting of approximately 160 graduate students and 70 faculty members. Ongoing research at the RSMAS is in the sub-disciplines of marine biology and living resources, marine geology and geophysics, marine and atmospheric chemistry, meteorology and physical oceanography, applied marine physics, and marine affairs.

The training of students in the marine sciences is naturally a prime objective at the RSMAS, one which has been met with

Michael McClain, Division of Marine Geology and Geophysics: Charles Harden, Division of Biology and Living Resources: Rosenstiel School of Marine and Atmospheric Science, 4600 Rickenbacker Causeway, Miami. FL 33149

Editor's Note: We contimue to solicit hrief articles describing programs, activities, interests and concerns of graduate or undergraduate oceanography students, who are also reminded of the Telemail bulletin board GRAD.STUDENTS that has been graciously provided for their benefit by Omnet, Inc. 